\title{
CELLULOSIC BIOETHANOL PRODUCTION FROM ULVA LACTUCA
}

\section{MACROALGAE}

\author{
AMINA ALLOUACHE,,${ }^{* * *}$ AZIZA MAJDA, ${ }^{*}$ AHMED ZAID TOUDERT, ${ }^{* *}$ \\ ABDELTIF AMRANE ${ }^{* * *}$ and MERCEDES BALLESTEROS ${ }^{* * * *}$ \\ *Centre de Développement des Energies Renouvelables, Division Bioénergies et Environnement Route de \\ l'Observatoire, B.P. 62, Bouzareah, 16340, Algiers, Algeria \\ ${ }^{* *}$ Ecole Nationale Polytechnique, Département de Génie Chimique, Laboratoire de Valorisation des \\ Energies Fossiles, 10 Avenue Hassen Badi, BP 182, El Harrach, 16200 Algiers, Algeria \\ ${ }^{* * *}$ Université de Rennes, Ecole Nationale Supérieure de Chimie de Rennes, CNRS, ISCR (Institut des \\ Sciences Chimiques de Rennes) - UMR 6226, F-35000 Rennes, France \\ ${ }^{* * * *}$ Centro de Investigaciones Energeticas, Medioambientales y Tecnologicas, Biofuels Unit, \\ Renewable Energies Department, Avda. Complutense, 40, Madrid, Spain \\ \Corresponding author: A. Allouache, a.allouache@cder.dz.
}

Received August 19, 2020

\begin{abstract}
Nowadays, the use of biofuels has become an unavoidable solution to the depletion of fossil fuels and global warming. The controversy over the use of food crops for the production of the first-generation biofuels and deforestation caused by the second-generation ones has forced the transition to the third generation of biofuels, which avoids the use of arable land and edible products, and does not threaten biodiversity. This generation is based on the marine and freshwater biomass, which has the advantages of being abundant or even invasive, easy to cultivate and having a good energetic potential. Bioethanol production from Ulva lactuca, a local marine macroalgae collected from the west coast of Algiers, was examined in this study. Ulva lactuca showed a good energetic potential due to its carbohydrate-rich content: $9.57 \%$ of cellulose, $6.9 \%$ of hemicellulose and low lignin content of $5.11 \%$. Ethanol was produced following the separate hydrolysis and fermentation process (SHF), preceded by a thermal acid pretreatment at $120{ }^{\circ} \mathrm{C}$ during 15 min. Enzymatic hydrolysis was performed using a commercial cellulase (Celluclast $1.5 \mathrm{~L}$ ), which saccharified the cellulose contained in the green seaweed, releasing about $85.01 \%$ of the total glucose, corresponding to $7.21 \mathrm{~g} / \mathrm{L}$ after $96 \mathrm{~h}$ of enzymatic hydrolysis at $\mathrm{pH} 5$ and $45^{\circ} \mathrm{C}$. About $3.52 \mathrm{~g} / \mathrm{L}$ of ethanol was produced after $48 \mathrm{~h}$ of fermentation using Saccharomyces cerevisiae at $30^{\circ} \mathrm{C}$ and $\mathrm{pH} 5$, leading to a high ethanol yield of $0.41 \mathrm{~g}$ of ethanol/g of glucose.
\end{abstract}

Keywords: renewable energy, biofuel, bioethanol, macroalgae, Ulva lactuca, SHF

\section{INTRODUCTION}

The integration of renewable energies into the Algerian energy mix is a major challenge in terms of reducing fossil fuel consumption, greenhouse gas emissions, and contributing to sustainable energy development. This program is at the heart of Algeria's energy and economic policy, notably in the transportation sector, which represents $24 \%$ of the Algerian total energy consumption and is responsible for the emission of 9574 tons of carbon dioxide equivalent. ${ }^{1}$

The consumption of fossil fuels in Algeria has recorded a high growth rate. It went from 0.6 million tons in 1964 to 14.9 million tons in 2016. The consumption of gasoline reached 4.3 million tons in 2016; its average annual growth rate consumption reached $8 \%$ over the period 20102016, against $3.9 \%$ for diesel and only $0.2 \%$ for liquefied petroleum gas (LPG) over the same period. $^{2}$

Algeria holds a huge biomass potential, which has been evaluated at more than $37 \mathrm{TOE}$ (tons of oil equivalent), without taking into account wastes evaluated at 1.33 TOE every year. ${ }^{3}$ The Renewable Energy Algerian Program aims to tap this potential to reach the target production of 1000 MW under the Horizon $2030,{ }^{4}$ which would result in an economy of more than 15 million TOE by $2030 .^{3}$

In this context, the contribution of bioenergy, notably biofuels, does not need to be proven 
anymore, whether from an economic or an ecological point of view. Global transport emissions increase by $1.9 \%$ annually (since 2000), and the transportation sector is responsible for $24 \%$ of the direct $\mathrm{CO}_{2}$ emissions caused by fuel combustion. Road vehicles - cars, trucks, buses and two- and three-wheelers - account for nearly three-quarters of transport $\mathrm{CO}_{2}$ emissions, while emissions from aviation and shipping continue to rise, highlighting the need for greater international policy focus on these hard-to-abate subsectors. ${ }^{5}$ The growth of the demand for gasoline and diesel is expected to weaken between 2019 and 2025, as countries around the world implement policies to improve efficiency and cut carbon dioxide $\left(\mathrm{CO}_{2}\right)$ emissions. ${ }^{6}$

International Energy Agency (IEA) forecasts indicate that global bioenergy consumption is in a constant increase, being projected to rise from 18 EJ (exajoule) in 2015 to $73 \mathrm{EJ}$ in 2060. The transportation sector is projected to pass from $4 \%$ to $41 \%$ in terms of global bioenergy consumption over the same period.

Biofuels, mainly ethanol and to a far lesser extent biodiesel, represent a modest $1.5 \mathrm{EJ}$ (about $1.5 \%)$ of the transport fuel used worldwide. The global interest in transport biofuels is growing, particularly in Europe, Brazil, North America, Japan, China and India. ${ }^{8}$ The global ethanol production, which is a substitute of gasoline, has more than doubled since 2000, and its demand is projected to increase 3.4 -fold by 2035 . $^{9}$

Cellulose, a structural component of plant biomass, is the most abundant feedstock on the earth; it is used for the production of alternative liquid fuels, mainly bioethanol. ${ }^{10}$ However, in terrestrial plants, cellulose is intertwined with lignin, hemicelluloses and pectin, which require extra energy input as pretreatment for their removal. Consequently, due to their high carbohydrates content, high productivity and widespread distribution, marine macroalgae (seaweeds) are increasingly gaining prominence as an alternative renewable feedstock for sustainable production of biofuels. ${ }^{11}$ Indeed, algae are characterized by the absence of lignin (occasionally, traces), which dispenses the need for energy-intensive pretreatment as part of the hydrolysis process prior to fermentation. ${ }^{12}$

Cellulose can be found in brown, red and green seaweed; however, in both red and brown algae the cellulose content is rather low. Most green algae have a cellulosic wall, with the cellulose content ranging up to $70 \%$ of the dry weight. $^{13}$

Among green seaweed, Ulva lactuca is one of the most abundant ones. It is a marine green alga, with the thallus with irregular leaves, ranging from dark green to green or light yellow in color. Its size generally varies between 20 and $60 \mathrm{~cm}$ long and can reach a meter in waters rich in organic matter. ${ }^{11}$ Sea lettuce generally grows on the supra-littoral stage, but can grow up to $10 \mathrm{~m}$ deep, on rocks, flooded rocks, shells and even on other seaweeds. This seaweed is often found on the shore of the beaches, because it is torn off by currents and is deposited there. ${ }^{14}$ In Algeria, it is present along almost the whole littoral. This seaweed is annual, with the lifetime of a few months, but can be found all year round, because it is renewed, especially in spring and summer. ${ }^{15}$ It is a rich source of carbohydrates (60-65\%), consisting of high-value sulphated polymer, ulvan, along with cellulose and hemicelluloses, and $4-5 \%$ lipids. Also, it has low lignin content and displays a high growth rate, adaptability to different climates, high biomass per acre yield and negligible need for fresh water, which makes it an excellent substrate for bioethanol production. $^{16}$

\section{EXPERIMENTAL}

\section{Ulva lactuca characterization}

Ulva lactuca samples were collected in Bouharoun (Tipaza, Algeria), which is about fifty kilometers west of the capital Algiers. The samples were transported, washed, soaked in water to remove salt, dried and milled.

The obtained powder had a particle size between $180 \mu \mathrm{m}$ and $850 \mu \mathrm{m}$ - the fraction selected passed through an $850 \mu \mathrm{m}$ mesh sieve and was retained by a $180 \mu \mathrm{m}$ mesh sieve; this fraction was conserved for future experiments.

The carbohydrates composition of Ulva lactuca was determined following NREL methods, according to which the polymeric carbohydrates were hydrolyzed into their monomeric forms, which are soluble in the hydrolysis liquid. ${ }^{17}$ Ulva powder was first extracted in a Soxhlet extractor for $18 \mathrm{~h}$, dried in a rotary evaporator, and then hydrolyzed twice (in concentrated sulfuric acid at low temperature $\left(72 \% \mathrm{H}_{2} \mathrm{SO}_{4}\right.$ at $30{ }^{\circ} \mathrm{C}$ for 1 hour) and in diluted acid $\left(4 \% \mathrm{H}_{2} \mathrm{SO}_{4}\right)$ at high temperature (water is added to the algae/acid mixture and autoclaved at $120^{\circ} \mathrm{C}$ for 1 hour). ${ }^{17}$

Sugars were measured by HPLC using a CARBOSep CHO $782 \mathrm{~Pb}$ column. HPLC conditions were as follows: injection volume of $10-50 \mu \mathrm{L}$; mobile phase: HPLC grade water, $0.2 \mu \mathrm{m}$, filtered and degassed; flow rate of $0.6 \mathrm{~mL} / \mathrm{min}$; column 
temperature of $80-85^{\circ} \mathrm{C}$; detector temperature: as close as possible to column temperature; run time: $35 \mathrm{~min}$.

The sugar content in $\mathrm{g} / \mathrm{L}$ was obtained by HPLC, and $\%$ sugar was calculated following these equations: ${ }^{17}$

$\%$ sugar $=(\%$ sugar ext free $) \times \frac{(100-\% \text { extractives })}{100}$

$\%$ sugar $_{\text {ext free }}=\frac{C H P L C \times V f}{D W} \times 100$

where sugar $_{\text {ext }}$ free $=$ percentage of sugar on an extractives-free basis, $\mathrm{C}_{\mathrm{HPLC}}=$ concentration of a sugar as determined by HPLC, $\%$ extractives = percent extractives in the prepared biomass sample, $V_{\mathrm{f}}=$ volume of filtrate, DW = dry weight of initial sample (dried at $105^{\circ} \mathrm{C}$ ).

Polysaccharides content was determined by the following equations: ${ }^{17}$

Cellulose content $=$ total glucan - starch content

Glucan content $=$ glucose content $/ 1.1$

Hemicellulose content $=($ xylose $/ 1.13)$

$($ galactose/1.1 $)+($ mannose/1.1 $)+($ arabinose/1.13 $)$

The ash content was determined following the NREL protocol. ${ }^{19}$ Three crucibles were placed in a muffle furnace at $575 \pm 25{ }^{\circ} \mathrm{C}$ for a minimum of four hours and then transferred directly into a desiccator. The crucibles were weighed and placed back into the muffle furnace at $575 \pm 25{ }^{\circ} \mathrm{C}$ until constant weight.

The ash content was calculated following the equation: ${ }^{18}$

$\%$ Ash $=\frac{(\mathrm{Wc}+\mathrm{a})-W c}{D W} \times 100$

where $\mathrm{W}_{\mathrm{c}+\mathrm{a}}=$ crucible weight + ash, $\mathrm{W}_{\mathrm{c}}=$ crucible weight, DW = dry weight of initial sample.

Lignin fractionates into acid insoluble material and acid soluble material. Total lignin $\left(\operatorname{lignin}_{\mathrm{T}}\right)$ was calculated following the equation: ${ }^{17}$

$\% \operatorname{lignin}_{\mathrm{T}}=\% \operatorname{lignin}_{\mathrm{AS}}+\% \operatorname{lignin}_{\mathrm{AI}}$

where $\operatorname{lignin}_{\mathrm{AS}}=$ acid soluble lignin, $\operatorname{lignin}_{\mathrm{AI}}=$ acid insoluble lignin.

To measure the lignin content, the previously autoclaved hydrolysis solution prepared for carbohydrates determination was cooled and vacuum filtered through a weighed filtering crucible.

To determine acid insoluble lignin, the crucible was dried at $105 \pm 3{ }^{\circ} \mathrm{C}$ until a constant weight was reached, then it was cooled and placed in a muffle furnace at $575 \pm 25{ }^{\circ} \mathrm{C}$ for $24 \pm 6$ hours. After being cooled, the crucible weight was recorded and then placed back in the furnace until constant weight. ${ }^{17}$

$$
\% \text { LigninAS }=\frac{(W c+a-W c)-(W c+a s h-W c)}{D W} \times 100
$$

where $\mathrm{W}_{\mathrm{c}+\mathrm{a}}=$ weight of crucible + oven dried biomass, $\mathrm{W}_{\mathrm{c}}=$ weight of crucible, $\mathrm{W}_{\mathrm{c}+\text { ash }}=$ weight of crucible plus ash, DW = dry weight of initial sample.

Acid soluble lignin content was assessed by measuring the absorbance of the autoclaved hydrolysis solution prepared to evaluate carbohydrates content, on a UV-Visible spectrophotometer at a wavelength of $205 \mathrm{~nm}$; a factor dilution of 40 was used to bring the absorbance into the range of $0.2-0.7::^{19}$

$\%$ acid soluble lignin $=\frac{U V \text { abs } \times V f \times D}{\varepsilon \times D W} \times 100$

where UVabs $=$ absorbance at $205 \mathrm{~nm}, \mathrm{~V}_{\mathrm{f}}=$ volume of filtrate $(87 \mathrm{~mL}), \mathrm{D}=$ dilution $(40), \mathrm{DW}=$ dry weight, $\varepsilon$ $=$ Extinction coefficient $(=110 \mathrm{~L} / \mathrm{g} \mathrm{cm}$ for absorbance between 0.2 and 0.7 at $205 \mathrm{~nm}){ }^{19}$

\section{Pretreatment}

Ulva lactuca powder was homogeneously suspended in water at a concentration of $3 \%(\mathrm{w} / \mathrm{w})$, using a magnetic stirrer during $30 \mathrm{~min}$, then $1 \%$ of sulfuric acid was added. The $\mathrm{pH}$ value was 1.5 before it was adjusted to 2.5. The suspension was autoclaved at $120{ }^{\circ} \mathrm{C}$ during $15 \mathrm{~min}$, then it was cooled and filtered.

After this, the biomass residue collected on the filter was washed and dried, and used as substrate for enzymatic hydrolysis.

\section{Separate hydrolysis and fermentation (SHF) Enzymatic activity study}

Commercial grade cellulase from Trichoderma reesei (Celluclast ${ }^{\circledR} 1.5 \mathrm{~L}$ ) was used as enzyme in this study. The enzymatic activity was calculated to determine the volume needed to hydrolyse the substrate. $20 \mu \mathrm{L}$ of diluted enzyme $(1 / 2000)$ was added to $40 \mu \mathrm{L}$ of $50 \mathrm{Mm}$ citrate buffer ( $\mathrm{pH}$ ) in microtubes containing a filter paper disk of $5.5 \mathrm{~mm}$ diameter. The microtubes were incubated at $50{ }^{\circ} \mathrm{C}$ for 1 hour without agitation. $120 \mu \mathrm{L}$ of DNS (3,5-Dinitrosalicylic acid) was added into the tubes and the mixture was then mixed on a vortex mixer, before being boiled for 5 min. $36 \mu \mathrm{L}$ of the reaction product was transferred into $160 \mu \mathrm{L}$ of water in a flat-bottomed microplate. Using a UV-Visible spectrophotometer, the absorbance was read at $540 \mathrm{~nm}$.

The enzymatic activity was calculated according to the following formula: ${ }^{20}$

$\mathrm{FPU} / \mathrm{mL}=\mathrm{mg}$ glucose released $\times 1000 / 180 / 60 /$ $0.02=\mathrm{mg}$ glucose released $\times 4.629$

\section{Saccharification}

Acid pretreated Ulva lactuca powder was suspended in citrate buffer $(\mathrm{pH} 5)$ at $5 \%(\mathrm{w} / \mathrm{w})$ consistency. Enzymatic hydrolysis started with the addition of $20 \mathrm{FPU} / \mathrm{g}$ of Celluclast to the suspension. The enzymatic hydrolysis was carried out in a shaker at $\mathrm{pH} 5$, the temperature of $45^{\circ} \mathrm{C}$ at a stirring speed of $200 \mathrm{rpm}$ for 96 hours. The solution was filtered and the supernatant was recovered. The glucose released was analyzed daily by HPLC.

\section{Fermentation}

After enzymatic hydrolysis, the suspensions were supplemented with $\left(\mathrm{NH}_{4}\right)_{2} \mathrm{HPO}_{4}$ solution at a 
concentration of $0.5 \mathrm{~g} / \mathrm{L}$ and then fermented by yeasts. The yeast was added in the form of a preculture prepared from a strain cultivated on an YMA plate transferred to a Yeast Malt Agar (YMA) liquid tube incubated during $18 \mathrm{~h}$. The fermentation was carried out at $30{ }^{\circ} \mathrm{C}$, at a stirring speed of $250 \mathrm{rpm}$ for 48 hours at $\mathrm{pH} 5$.

All the samples were centrifuged and filtered through a $45 \mu \mathrm{m}$ filter syringe before daily glucose and ethanol measurements by HPLC, under the following operation conditions: injection volume of $20 \mu \mathrm{L}$; run time of $30 \mathrm{~min}$; mobile phase: $\mathrm{H}_{2} \mathrm{SO}_{4} 0.02 \mathrm{M}$; flow rate of $0.8 \mathrm{~mL} / \mathrm{min}$; column temperature of $60{ }^{\circ} \mathrm{C}$.

We considered a theoretical yield of bioethanol of $0.51 \mathrm{~g}$ per one gram of glucose consumed during fermentation. ${ }^{21}$

Ethanol conversion as \% of the theoretical $\left(\mathrm{Th}_{\mathrm{y}}\right)$ was calculated according to the following formula: ${ }^{22}$

$\operatorname{Th}_{\mathrm{y}}(\%)=\left(\mathrm{A}_{\mathrm{y}} \mathrm{x} 100\right) / 0.51$

where $A_{y}=$ the actual ethanol produced and expressed as $g$ ethanol per $g$ sugar utilized $\left(\mathrm{g} \mathrm{g}^{-1}\right) .^{22}$

\section{RESULTS AND DISCUSSION Ulva lactuca composition}

The complete hydrolysis of Ulva lactuca powder allowed evaluating the polysaccharides, lignin and ash contents. The results are tabulated in Table 1. As may be noted in Table 1, the composition in monomeric sugars is diversified, 5 different monomers were found, while glucose, galactose and xylose showed very interesting recovery rates. These fermentable sugars can be converted into ethanol, when the appropriate biosystem is used.

The content of carbohydrates in Ulva lactuca, as calculated from their monomeric form, shows interesting results, especially for cellulose, resulting from the good rates of glucose; total sugars were $16.47 \%$ on dry weight basis. In general, the sugar content in green seaweeds is lower than that in other lignocellulosic feedstocks. Similar polysaccharide composition was reported by B. Dubigeon et al. ${ }^{23}$ and $\mathrm{H}$. van der Wal. ${ }^{24}$

The results also reveal a low total lignin faction, estimated at $5.11 \% \mathrm{w} / \mathrm{w}$, which is negligible compared with the lignin fraction in terrestrial plants. This component present in more significant amounts in higher plants is very difficult to degrade biologically and cannot be fermented. $^{25}$ In this study, only $1 \%$ of sulfuric acid and a treatment duration of $15 \mathrm{~min}$ were sufficient to pretreat Ulva lactuca powder. In general, the absolute or near absence of lignin makes the enzymatic hydrolysis of algal cellulose simple. $^{26}$

\section{Celluclast enzymatic activity}

Celluclast enzymatic activity, expressed in FPase (filter paper activity), is given in Table 2. As shown in the table, the Celluclast filter paper activity was $68.656 \mathrm{FPU} / \mathrm{mL}$; this result reflects good performance of the commercial enzyme, allowing to work with the smallest enzyme volume that guarantees the maximum efficiency. Based on this result and working with 20 FPU per gram of algal substrate, the enzyme volume needed to hydrolyze algal cellulose was $218 \mu \mathrm{L} / \mathrm{g}$ of substrate.

\section{Saccharification}

Table 3 presents the results of released glucose during enzymatic saccharification.

The major advantage of separate hydrolysis and fermentation (SHF) is that the hydrolysis and the fermentation processes can be carried out each under their optimal conditions. However, in general, SHF requires longer overall process time, in comparison with simultaneous saccharification and fermentation (SSF). ${ }^{27}$ Also, the end-product inhibition of enzymes induced by glucose and cellobiose results in a reduced rate of saccharification. $^{28}$

The daily glucose concentration (Table 3) indicates that glucose release started slowly the first two days and then accelerated. Thus, 7.21 $\mathrm{g} / \mathrm{L}$ was produced after 4 days of saccharification, which is of the same order of magnitude as the total amount of glucose contained in Ulva lactuca, $8.481 \mathrm{~g} / \mathrm{L}$ (Table 1), showing an enzyme efficiency of $85.01 \%$, indicative of good Celluclast efficiency.

\section{Fermentation}

Fermentation was carried out on the Ulva lactuca suspension previously pretreated and hydrolysed by Celluclast during 4 days. The corresponding results are given in Figure 1.

As shown in Figure 1, $6.04 \mathrm{~g} / \mathrm{L}$ of glucose was consumed the first $24 \mathrm{~h}$ of fermentation, corresponding to a consumption of $83.78 \%$ of the total glucose. The remaining $1.17 \mathrm{~g} / \mathrm{L}$ of glucose was consumed within the second day. 
Table 1

Composition of Ulva lactuca

\begin{tabular}{|c|c|c|c|c|c|c|}
\hline \multirow[b]{2}{*}{ Component } & \multirow{2}{*}{$\begin{array}{c}\text { Sugars concentration } \\
\text { determined by HPLC } \\
(\mathrm{g} / \mathrm{L})\end{array}$} & \multirow{2}{*}{\multicolumn{3}{|c|}{$\begin{array}{l}\text { Sugars percentage on } \\
\text { received biomass basis } \\
(\% \mathrm{w} / \mathrm{w})\end{array}$}} & \multicolumn{2}{|c|}{ Summary of Ulva lactuca composition (\%) } \\
\hline & & & & & Extractives & $47.89 \pm 3.58 \%$ \\
\hline Glucose & $8.48 \pm 0.76$ & $10.61 \pm 0.40$ & Glucan & $9.56 \pm 0.32$ & Cellulose & $9.57 \pm 0.36 \%$ \\
\hline Xylose & $1.89 \pm 0.07$ & & $2.37 \pm 0.04$ & & \multirow{4}{*}{ Hemicelluloses } & \multirow{4}{*}{$6.9 \pm 0.54 \%$} \\
\hline Galactose & $4.02 \pm 1.004$ & & $5.03 \pm 0.52$ & & & \\
\hline Mannose & $0.06 \pm 0.01$ & & $0.08 \pm 0.001$ & & & \\
\hline \multirow[t]{5}{*}{ Arabinose } & $0.12 \pm 0.05$ & & $0.16 \pm 0.02$ & & & \\
\hline & & & & & Acid insoluble lignin & $2.57 \pm 0.36$ \\
\hline & & & & & Acid soluble lignin & $2.54 \pm 0.07$ \\
\hline & & & & & Ash & $25.7 \pm 1.03$ \\
\hline & & & & & Total & $95.2 \%$ \\
\hline
\end{tabular}

Table 2

Celluclast filter paper activity (FPU/mL)

\begin{tabular}{lcccc}
\hline Absorbance & $\begin{array}{c}\text { Glucose produced during } \\
\text { enzymatic hydrolysis } \\
(\mathrm{mg})\end{array}$ & $\begin{array}{c}\text { Glucose produced during } \\
\text { enzymatic hydrolysis } \\
(\mu \mathrm{mol} / \mathrm{mL} \mathrm{min})\end{array}$ & Dilution & $\begin{array}{c}\text { Enzymatic activity } \\
(\mathrm{FPU} / \mathrm{mL})\end{array}$ \\
\hline $0.137 \pm 0.06$ & $0.007 \pm 0.001$ & $0.034 \pm 0.008$ & 2000 & $68.65 \pm 11.38$ \\
\hline
\end{tabular}


Within $48 \mathrm{~h}$ of fermentation, all the glucose produced during enzymatic saccharification was consumed, leading, at the same time, to the production of $3.52 \mathrm{~g} / \mathrm{L}$ of ethanol. The resulting ethanol yield was close to the maximum theoretical rate that can be obtained, since it was estimated at $0.41 \mathrm{~g}$ ethanol/g sugars, representing $81.4 \%$ of the theoretical ethanol yield (Table 4 ). It should be noted that Lee and Lee, in their study on ethanol fermentation, reported the production of $2.59 \mathrm{~g} / \mathrm{L}$ of ethanol. ${ }^{29}$

Moreover, $2.5 \mathrm{~g} / \mathrm{L}$ of bioethanol produced from Ulva sp. was obtained by Akiko Isa, ${ }^{30}$ while only $0.2 \mathrm{~g} / \mathrm{L}$ of ethanol produced was achieved by $\mathrm{H}$. van der Wal from the same substrate. ${ }^{24}$

Table 3

Glucose yields during enzymatic saccharification of Ulva lactuca

\begin{tabular}{lcccc}
\hline Yield & $24 \mathrm{~h}$ & $48 \mathrm{~h}$ & $72 \mathrm{~h}$ & $96 \mathrm{~h}$ \\
\hline Glucose yield $(\mathrm{g} / \mathrm{L})$ & $1.19 \pm 0.02$ & $1.85 \pm 0.06$ & $5.42 \pm 0.51$ & $7.21 \pm 0.47$ \\
Glucose yield $(\%)$ & $14.03 \pm 0.02$ & $21.81 \pm 0.06$ & $63.90 \pm 0.51$ & $85.01 \pm 0.47$ \\
\hline
\end{tabular}

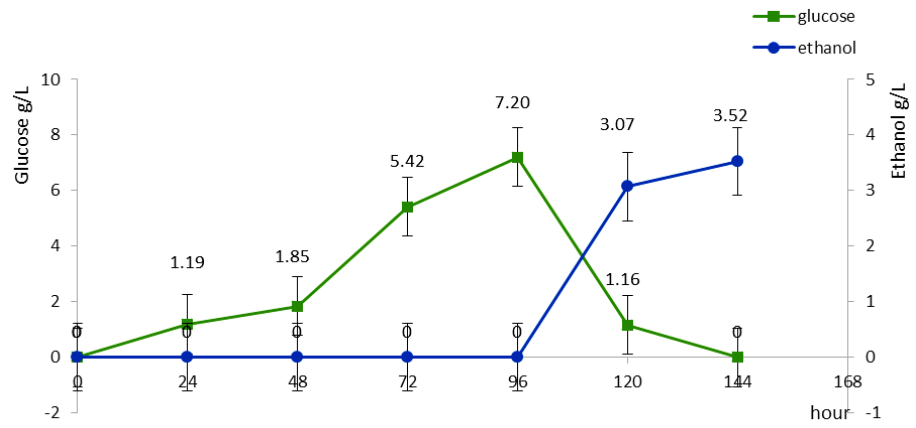

Figure 1: Separate saccharification and fermentation of Ulva lactuca hydrolysate

Table 4

Ethanol production $(\mathrm{g} / \mathrm{L})$ and ethanol yield during separate saccharification and fermentation of Ulva lactuca

\begin{tabular}{ccccc}
\hline $\begin{array}{c}\text { Time } \\
(\mathrm{h})\end{array}$ & $\begin{array}{c}\text { Glucose rate } \\
(\mathrm{g} / \mathrm{L})\end{array}$ & $\begin{array}{c}\text { Ethanol produced } \\
(\mathrm{g} / \mathrm{L})\end{array}$ & $\begin{array}{c}\text { Ethanol yield } \\
(\mathrm{g} \text { eth/g glc })\end{array}$ & $\begin{array}{c}\text { Ethanol yield } \\
(\% \text { of the theoretical })\end{array}$ \\
\hline 0 & 0 & 0 & 0 & 0 \\
24 & 1.19 & 0 & 0 & 0 \\
48 & 1.85 & 0 & 0 & 0 \\
72 & 5.42 & 0 & 0 & 0 \\
96 & 7.20 & 0 & 0 & 0 \\
120 & 1.16 & 3.07 & 0.36 & 70.98 \\
144 & 0 & 3.52 & 0.41 & 81.40 \\
\hline
\end{tabular}

The ethanol yield recorded in the present study appears, therefore, especially promising if compared to the yields reported in the related literature, due to the good conditions used to perform this study and the quality of Algerian Ulva lactuca in terms of cellulose content.

\section{CONCLUSION}

This study describes a greener approach to produce bioethanol, since the substrate is a non- food marine seaweed found inshore in abundance, causing putrefaction and methane emission. The carbohydrates composition of Ulva lactuca makes it a good candidate for bioethanol production. Using the SHF method under optimized conditions, it gave an ethanol yield of $0.415 \mathrm{~g} / \mathrm{g}$ glucose, for $85.01 \%$ of enzymatic conversion efficiency. Furthermore, $0.41 \mathrm{~g}$ ethanol/g sugars, representing $81.4 \%$ of the theoretical ethanol yield, was achieved. 
In Algeria, seaweed represents an enormous potential to tap in order to limit fossil fuels consumption. Even if laboratory-scale algal biofuel production gave excellent ethanol concentration and conversion rates, the production at an industrial scale still represents a major challenge to be met in terms of large-scale seaweed cultivation, pretreatment, hydrolysis and fermentation at low cost, especially when using enzymes.

\section{REFERENCES}

Ministry of Energy and Mines, National Agency for the Promotion and Rationalization of Energy Use, Final Energy Consumption of Algeria, in APRUE 2007 ,

http://www.aprue.org.dz/documents/PUBLICATION\% 20CONSOMMATION\%20ENERGETIQUE\%20FIN ALE\%202015.pdf, accessed on 26/04/2021

2 Ministry of Energy, Hydrocarbons Regulatory Authority, National Land Fuels Market Report 2016, March 2017 , http://www.arh.gov.dz/pdf/synthese_publiable_cbr.pdf, accessed on $02 / 05 / 2021$

3 Ministry of Energy, Contribution of the Directorate of New and Renewable Energies and Energy Management, 2014,

https://www.energy.gov.dz/?rubrique=energies-

nouvelles-renouvelables-et-maitrise-de-lrenergie, accessed on 11/09/2019

4 Ministry of Energy, National Program for New and Renewable Energies, 2015, https://era.dz/salon/fr/content/programme-national-des$\% \mathrm{C} 3 \%$ A9nergies-nouvelles-et-renouvelables, accessed on $20 / 04 / 2021$

5 IEA, Tracking Transport 2020, Paris, 2020, https://www.iea.org/reports/tracking-transport-2020, accessed on 20/04/2021

6 IEA, Oil 2020, Paris, 2020, https://www.iea.org/reports/oil-2020, accessed on 20/04/2021

7 IEA Bioenergy Roadmap, 2017, https://www.ieabioenergy.com/bioenergy-asustainable-solution/, accessed on 20/08/2020

8 Potential Contribution of Bioenergy to the World's Future Energy Demand, IEA BIOENERGY: ExCO: 2007:02, https://www.ieabioenergy.com/wpcontent/uploads/2013/10/Potential-Contribution-ofBioenergy-to-the-Worlds-Future-Energy-Demand.pdf

9 IEA, World Energy Outlook 2012, Paris, 2012, https://www.iea.org/reports/world-energy-outlook2012, accessed on 20/04/2021

10 P. Chand, A. Aruna, A. M. Maqsood and L. V. Rao, J. Appl. Microbiol., 98, 318 (2005), https://doi.org/10.1111/j.1365-2672.2004.02453.x

11 C. E. Wyman and B. Yang, Calif. Agric., 63, 185 (2009), https://escholarship.org/uc/item/3rk3p6n3
12 N. Trivedi, C. R. K. Reddy, R. Radulovich and B. Jha, Algal Res., 9, 48 (2015), https://doi.org/10.1016/j.algal.2015.02.025

13 B. Baldan, P. Andolfo, L. Navazio, C. Tolomio and P. Mariani, Eur. J. Histochem., 45, 51 (2001), https://doi.org/10.4081/1613

14 P. Gayral, "Algae: Morphology, Cytology, Reproduction, Ecology”, Doin, Vol. 1, 1975, pp. 166

15 W. Benguedda Rahal, Doctoral Thesis, University of Tlemcen, Algeria, 2012, pp. 149

16 H. Yaich, H. Garna and S. Besbes, Food Chem., 128 895 (2011), https://doi.org/10.1016/j.foodchem.2011.03.114

17 A. Sluiter, B. Hames, R. Ruiz, C. Scarlata, J. Sluiter et al., Determination of Structural Carbohydrates and Lignin, in "Biomass Laboratory Analytical Procedure (LAP)", April 2008, revised August 2012

18 A. Sluiter, B. Hames, R. Ruiz, C. Scarlata, J. Sluiter et al., Determination of Ash in Biomass, in "Laboratory Analytical Procedure (LAP)", July 2005

19 TAPPI T 222 om-02 (2002), Acid-insoluble lignin in wood and pulp, TAPPI Test Methods 2002-2003, Tappi Press, Atlanta, GA, USA

20 T. K. Ghose, Pure Appl. Chem., 59, 257 (1987), http://dx.doi.org/10.1351/pac198759020257

21 K. L. Chin and P. S. H'ng, "A Real Story of Bioethanol from Biomass: Malaysia Perspective", Intech Open, 2013, pp. 331, http://dx.doi.org/10.5772/51198

22 T. Onsoy, P. Thanonkeo, S. Thanonkeo and M. Yamada, KMITL Sci. Tech. J., 7, 1 (2007)

${ }^{23}$ C. Bobin Dubigeon, M. Lahaye and J. L. Barry, $J$. Sci. Food Agric., 73, $149 \quad$ (1997), https://doi.org/10.1002/(SICI)10970010(199702)73:2<149::AID-JSFA685>3.0.CO;2-L 24 V. D. W. Hetty, B. Sperber and B. Houweling, Bioresour. Technol., 128, 431 (2013), https://doi.org/10.1016/j.biortech.2012.10.094

25 R. Harun, M. K. Danquah and G. M. Forde, J. Chem. Technol. Biotechnol., 85, 199 (2010), https://doi.org/10.1002/jctb.2287

26 J. P. Rojan, G. S. Anisha, K. Madhavan Nampoothiri and A. Pandey, Bioresour. Technol., 102, 186

(2011) https://doi.org/10.1016/j.biortech.2010.06.139

27 F. Alfani, A. Gallifuoco and A. Saporosi, J. Ind. Microbiol. Biot., 25, $184 \quad$ (2000), https://doi.org/10.1038/sj.jim.7000054.

28 E. Tomás-Pejó, J. M. Oliva, M. Ballesteros and L. Olsson, Biotechnol. Bioeng., 100, 1122 (2008), https://doi.org/10.1002/bit.21849

29 S.-M. Lee and J.-H. Lee, J. Ind. Eng. Chem., 18, 16 (2012), https://doi.org/10.1016/j.jiec.2011.11.097

30 A. Isa, Y. Mishima, O. Takimura and T. Minowa, $J$. Japan Inst. Energ., 88, $912 \quad$ (2009), https://doi.org/10.3775/jie.88.912 